\title{
Seasonal variation in the relative utilization of dietary protein for energy and biosynthesis by the mussel Mytilus edulis
}

\author{
D. A. Kreeger ${ }^{1, *}$, A. J. S. Hawkins ${ }^{2}$, B. L. Bayne ${ }^{2}$, D. M. Lowe ${ }^{2}$ \\ 'Environmental Research Division, Academy of Natural Sciences, 1900 Benjamin Franklin Parkway, Philadelphia, \\ Pennsylvania 19103, USA \\ ${ }^{2}$ Plymouth Marine Laboratory, Prospect Place, The Hoe, Plymouth, Devon PL1 3DH, United Kingdom
}

\begin{abstract}
Mussels Mytilus edulis were collected from Whitsand Bay in southwest England during April, July and September 1993 and January 1994, and fed a defined diet of prekilled microalgae with one of 2 types of mixed protein/carbohydrate microcapsules. Both capsule types were comprised of the same $\mathrm{w} / \mathrm{w}$ proportion of ${ }^{15} \mathrm{~N}$-labeled protein and nonlabeled carbohydrate. However, Types 1 and 2 contained trace amounts of $\left[{ }^{14} \mathrm{C}\right]$ carbohydrate and $\left[{ }^{14} \mathrm{C}\right]$ protein, respectively. Defecation, excretion, respiration and incorporation of ${ }^{14} \mathrm{C}$ and ${ }^{15} \mathrm{~N}$ isotopes were measured to describe the mussel's relative utilization of dietary carbohydrate $\left({ }^{14} \mathrm{C}\right.$ from Type 1$)$, protein- $\mathrm{C}\left({ }^{14} \mathrm{C}\right.$ from Type 2$)$ and protein- $\mathrm{N}\left({ }^{15} \mathrm{~N}\right.$ from Types 1 and 2). In each experiment, mussels ingested similar quantities of capsule Types 1 and 2. However, the ${ }^{14} \mathrm{C}$-assimilation efficiency for carbohydrate (16 to $20 \%$ ) was significantly greater than the ${ }^{14} \mathrm{C}$-assimilation efficiency for protein ( 7 to $15 \%$ ). In contrast, protein-N was always assimilated with greater efficiency $(25$ to $82 \%$ ) than either carbohydrate or protein-C. The difference in assimilation efficiency between protein- $\mathrm{N}$ and protein- $\mathrm{C}$ indicates that a large proportion of amino acids from dietary protein were hydrolyzed, with amino- $\mathrm{N}$ being preferentially assimilated. The relatively poor assimilation of amino-C indicates that mussels were not nutritionally limited by energy since amino-C generated by the energy-intensive digestion process was not fully catabolized in the tricarboxylic acid cycle (i.e. not respired). The conservation of protein- $N$ relative to protein- $C$ was particularly noticeable in July when rates of ingestion and ammonia excretion were lowest, $<1 \%$ of absorbed $\left[{ }^{15} \mathrm{~N}\right]$ protein was excreted, and $\left[{ }^{15} \mathrm{~N}\right]$ protein assimilation was 5 times more efficient than $\left[{ }^{14} \mathrm{C}\right]$ protein assimilation. Further, rates of protein synthesis were greatest in July (71.2 $\left.\mathrm{mg} \mathrm{d}^{-1}\right)$, compared with April, September and January $\left(39.2,58.9\right.$ and $\left.20.5 \mathrm{mg} \mathrm{d}^{-1}\right)$. These findings suggest that seasonal variation in dietary protein utilization in $M$. edulis is governed chiefly by changing anabolic demands for amino- $N$, rather than by requirements for energy or essential amino acids.
\end{abstract}

KEY WORDS: Protein - Carbohydrate $\cdot$ Mytilus edulis $\cdot$ Microcapsule $\cdot$ Assimilation

\section{INTRODUCTION}

Suspension-feeding bivalves living in temperate habitats undergo dramatic seasonal changes in physiological condition, with associated changes in their nutritional requirements for energy and protein (for reviews, see Bayne \& Newell 1983, Hawkins \& Bayne 1991, 1992). To properly understand the physiological ecology of these animals, it is necessary to determine how they meet changeable requirements from a diet

•E-mail: kreeger@say.acnatsci.org that also varies spatially and temporally in both availability and quality (Burt 1955, Van Valkenburg et al 1978, Chanut \& Poulet 1982, Soniat et al. 1984, Berg \& Newell 1986, Mayzaud et al. 1989, Sommer 1989, Langdon \& Newell 1990, Galvao \& Fritz 1991, Fegley et al. 1992, Urabe 1993, Cranford \& Hargrave 1994).

Suspension-feeders possess a wide array of physiological adaptations and alternative feeding strategies with which they balance nutrient uptake and loss. For example, some species compensate for variable food abundance by regulation of filtration rates and/or pseudofecal rejection rates (Winter 1976, Kiørboe et al. 
1980, Kiørboe \& Mohlenberg 1981, MacDonald \& Ward 1994). Pre-ingestion particle selection has also been suggested as an important mechanism with which suspension-feeders increase food quality (Kiørboe et al. 1980, Kiørboe \& Møhlenberg 1981, Newell \& Jordan 1983, Bricelj \& Malouf 1984, Bayne et al. 1989 , 1993, Prins \& Smaal 1989, Prins et al. 1991, Iglesias et al. 1992, Navarro et al. 1992, MacDonald \& Ward 1994, A. J. S. Hawkins, R. F. M. Smith, S. Bougrier, B. L. Bayne \& M. Héral unpubl., A. J. S. Hawkins, R. F. M. Smith, B. L. Bayne \& M. Héral unpubl.). In studying how suspension-feeders meet their nutritional requirements, however, relatively few studies have identified post-ingestion, digestive and metabolic adaptations for the differential utilization of dietary energy and nutrients.

Protein uptake is critical for all animals because it supplies essential amino acids and amino-nitrogen for biosynthesis. Several workers (Kreeger 1993, Hawkins 1985, Hawkins \& Bayne 1985) have reported that protein assimilation rates vary seasonally in suspensionfeeding bivalves. However, assimilated protein can be catabolized to satisfy an animal's energy requirements in addition to being used for biosynthesis. Mussels can also help satisfy anabolic demands for specific amino acids by turning over (i.e. mobilizing) endogenous pools of amino-N (Hawkins 1985). Relationships between protein and energy flux are further complicated because digestion of exogenous protein, turnover of endogenous amino- $N$, and the synthesis of protein from amino- $N$ are energy-demanding processes (for reviews, see Hawkins 1991, Hawkins \& Bayne 1992). Nonetheless, these relationships between energy and protein balance are fundamentally important in determining bivalve nutrition.

The relative utilization of dietary protein for energy and/or biosynthesis has been poorly studied because of technical limitations in discerning the fate of assimilated protein. Ratios of oxygen consumption to ammonia- $\mathrm{N}$ excretion ( $\mathrm{O} / \mathrm{N}$ ratios) are useful indicators of whether protein (low ratios) or carbohydrate (high ratios) is the chief catabolic substrate. $\mathrm{O} / \mathrm{N}$ ratios have suggested (Bayne 1973a, b, Bayne \& Widdows 1978) that the primary energy source in mussels Mytilus edulis is protein during gametogenesis and carbohydrate during the post-spawning quiescent period. $\mathrm{O} / \mathrm{N}$ ratios do not, however, supply information on the relative contribution of these substrates in anabolic processes, and they do not distinguish whether catabolized substrates are derived from the diet (i.e. exogenous) or tissues (i.e. turnover of endogenous reserves). In this study, the relative utilization of ingested protein and energy was compared in $M$. edulis using a new dual-isotope/microencapsulation approach (Kreeger et al. in press), which allows the anabolic and cata- bolic fates of dietary carbohydrate (primarily used for energy), protein-C (used for energy and biosynthesis) and protein-N (primarily used for biosynthesis) to be discerned simultaneously. The approach was repeated 4 times during the year, and patterns of protein utilization were related to seasonal changes in physiological condition and biosynthetic requirements.

\section{METHODS}

In April, July and September 1993 and January 1994, approximately 30 adult Mytilus edulis [shell heights 40 to $47 \mathrm{~mm}$, ash-free dry tissue weights (AFDTW) 110 to $620 \mathrm{mg}$ ] were collected from Whitsand Bay, southwest England. After being held in a laboratory system of recirculating seawater overnight, they were divided into 2 groups, and each individual was then fed on a 'pulse' of one of 2 isotopically labeled experimental diets for $3 \mathrm{~h}$. During both acclimation and pulse periods, the diet consisted of a $1: 2(d r y w / w)$ mixture of non-labeled prekilled microalgae Isochrysis galbana and mixed protein/carbohydrate microcapsules (PC capsules). The biochemical composition of PC capsules was the same throughout these experiments. However, PC capsules delivered to mussels during the pulse contained ${ }^{15} \mathrm{~N}$-labeled protein and a trace quantity of either ${ }^{14} \mathrm{C}$-labeled carbohydrate (Type 1 ) or ${ }^{14} \mathrm{C}$ labeled protein (Type 2). The duration of the pulse was assumed to be long enough for mussels to ingest a significant amount of the experimental diet, yet short enough to preclude the defecation, respiration or excretion of ingested material (see also Kreeger et al. in press). Following the pulse, mussels were transferred to clean seawater and fed non-labeled PC capsules for a $24 \mathrm{~h}$ 'chase' period, which was sufficient time to allow their guts to purge undigested, labeled diet. Detailed methods for the preparation of isotopically labeled substrates for encapsulation, preparation of $\mathrm{PC}$ capsules and algal diets, and the quantitative delivery of experimental diets are described by Kreeger et al. (in press).

The fate of isotopes ingested during the pulse was assessed by quantifying the resulting defecation of ${ }^{14} \mathrm{C}$ and ${ }^{15} \mathrm{~N}$ during purging, excretion of $\left[{ }^{14} \mathrm{C}\right.$ ]DOM (dissolved organic matter) and $\left[{ }^{15} \mathrm{~N} \mathrm{H}_{4}{ }^{+}\right.$during purging, respiration of ${ }^{14} \mathrm{CO}_{2}$ during purging, and tissue incorporation of ${ }^{14} \mathrm{C}$ and ${ }^{15} \mathrm{~N}$ at the end of purging (for methods, see Kreeger et al. in press). Ingestion of ${ }^{14} \mathrm{C}$ was calculated as the sum of ${ }^{14} \mathrm{C}$ defecated, excreted, respired and incorporated. Ingestion of ${ }^{15} \mathrm{~N}$ was calculated by multiplying ${ }^{14} \mathrm{C}$ ingestion by the dietary ratio of $\mu \mathrm{g}{ }^{15} \mathrm{~N}$ :dpm ${ }^{14} \mathrm{C}$. Defecation of ${ }^{15} \mathrm{~N}$ was calculated as the difference between ${ }^{15} \mathrm{~N}$ ingestion and the sum of ${ }^{15} \mathrm{~N}$ incorporation and ${ }^{15} \mathrm{~N}$ excretion. Methods for the 
collection, treatment and isotope quantification of fecal samples, water samples and mussel tissues are supplied elsewhere (Kreeger et al, in press). The ${ }^{14} \mathrm{C}$ and ${ }^{15} \mathrm{~N}$ budgets were calculated for individual mussels (Kreeger et al. in press), standardized for mussel AFDTW, and compared among treatments to ascertain whether Mytilus edulis assimilates and/or catabolizes dietary carbohydrate $\left({ }^{14} \mathrm{C}\right.$ in Type 1$)$, protein-C $\left({ }^{14} \mathrm{C}\right.$ in Type 2) and protein- $\mathrm{N}\left({ }^{15} \mathrm{~N}\right.$ in Types 1 and 2$)$ differently, and whether seasonal variations in physiological condition and protein requirements affect these utilization patterns.

Seasonal variability in the physiological condition of Mytilus edulis was examined by quantifying their reproductive condition. Twenty-five additional mussels were collected during each experiment and their mantle tissues were immediately dissected and frozen in liquid $\mathrm{N}_{2}$. The proportion of mantle tissue occupied by ripe gametes ('gamete volume fraction') was later analyzed from these frozen samples (for method, see Lowe et al. 1982) as an index of reproductive condition. To assess the extent to which the utilization of protein$\mathrm{N}$ is determined by biosynthetic demand, seasonal changes in the rate of whole-body protein synthesis were calculated from the ${ }^{15} \mathrm{~N}$ budget using the approach devised by Hawkins (1985).

Statistical treatment of resulting data consisted of ANOVAs, 2-way ANOVAs, and Tukey's multiple range analyses. Percentages (e.g. assimilation efficiencies, reproductive conditions) were arcsine square-root transformed prior to statistical evaluation.

\section{RESULTS}

The ${ }^{14} \mathrm{C}$ budget of Mytilus edulis fed PC capsules containing either $\left[{ }^{14} \mathrm{C}\right]$ carbohydrate (Type 1) or $1^{14} \mathrm{C}$ protein (Type 2) is summarized in Table 1 . A 2way ANOVA comparing the effects of capsule type and experiment month indicated that ${ }^{14} \mathrm{C}$ ingestion did not differ significantly between mussels fed Type 1 or Type 2 capsules. However, ${ }^{14} \mathrm{C}$-ingestion varied more than 10-fold [67 to $1206 \mathrm{dpm}$ (g AFDTW) ${ }^{-1}$ ] among experiments (Table 1). Although mussels defecated most ingested ${ }^{14} \mathrm{C}$ regardless of capsule type and experiment, ${ }^{14} \mathrm{C}$ defecation varied significantly (2-way ANOVA) between capsule types ( $<<0.0001)$ and among experiments ( $p<0.0001)$ (Table 1). Absorption (i.e. ingestion - defecation) comprised a greater proportion of the ${ }^{14} \mathrm{C}$ budget in mussels fed encapsulated $\left[{ }^{14} \mathrm{C}\right.$ carbohydrate $(23$ to $41 \%$ ) compared with $\left[{ }^{14} \mathrm{C}\right.$ )protein (9 to $25 \%$ ). When compared among experiments, significantly more ingested ${ }^{14} \mathrm{C}$ was absorbed in April (33\%) than in July (23\%), September (15\%) or January $(19 \%)$.
Mussels utilized a substantially greater proportion of ingested $\left[{ }^{14} \mathrm{C}\right]$ carbohydrate than $\left[{ }^{14} \mathrm{C}\right]$ protein (Table 1 ). Two-way ANOVAs comparing the relative effects of capsule type and experiment month indicated that ${ }^{14} \mathrm{C}$ excretion, ${ }^{14} \mathrm{C}$ respiration and ${ }^{14} \mathrm{C}$ incorporation represented a significantly $(\mathrm{p}<0.001)$ greater proportion of ingested ${ }^{14} \mathrm{C}$ when Mytilus edulis were fed $\left[{ }^{14} \mathrm{C}\right.$ ]carbohydrate $(8.9,0.3$ and $13.8 \%$, respectively) compared with $\left[{ }^{14} \mathrm{C}\right]$ protein $(5.1,0.2$ and $7.7 \%$, respectively). Seasonal variability was significant for ${ }^{14} \mathrm{C}$ excretion $(\mathrm{p}<$ 0.0001 ) and ${ }^{14} \mathrm{C}$ respiration ( $\mathrm{p}=0.0013$ ), but not for ${ }^{14} \mathrm{C}$ incorporation $(p>0.05)$. Excretion of ${ }^{14} \mathrm{C}$ was particularly variable ( 2 to $22 \%$ ) (Table 1 ), and in July differed markedly between mussels fed capsule Types 1 (18\%) and $2(4 \%)$. Such high and variable excretion has been reported before in similar isotope balance studies (Kreeger 1993, Kreeger \& Langdon 1994), and it is

Table 1. Mytilus edulis. Components of the ${ }^{14} \mathrm{C}$ budget of mussels fed mixed protein/carbohydrate microcapsules containing trace amounts of either $\left[{ }^{54} \mathrm{C}\right]$ carbohydrate (Type 1) or $\left[{ }^{14} \mathrm{C}\right]$ protein (Type 2). Mean $( \pm \mathrm{SE}){ }^{14} \mathrm{C}$-specific activity for each component is expressed as a percentage of ingested ${ }^{14} \mathrm{C}$, except for ${ }^{14} \mathrm{C}$ ingestion, which is given as the actual ${ }^{14} \mathrm{C}$ activities per mussel AFDTW. For each component, means were statistically compared between treatments $(n=2)$ and among experiments $(n=4)$ using ANOVA (percentages were arcsine square-root transformed before analysis); different superscripted letters indicate significant $(p<0.05)$ differences among these 8 means

\begin{tabular}{|c|c|c|c|}
\hline Month & $\begin{array}{c}\text { From } \\
\left.l^{14} \mathrm{C}\right] \text { carbohydrate }\end{array}$ & $\begin{array}{c}\text { From } \\
{\left[{ }^{14} \mathrm{C}\right] \text { protein }}\end{array}$ & $\mathrm{p}$ \\
\hline \multicolumn{4}{|c|}{ Ingestion (I) $\left[\mathrm{dpm} \times 10^{3}(\mathrm{~g} \text { AFDTW })^{-1}\right]$} \\
\hline Apr & $666 \pm 91^{\mathrm{B}}$ & $802 \pm 179^{\mathrm{B}}$ & \multirow{4}{*}{$<0.0001$} \\
\hline Jul & $88.8 \pm 19.8^{D}$ & $66.5 \pm 13.7^{D}$ & \\
\hline Sep & $356 \pm 49^{\circ}$ & $337 \pm 51^{c}$ & \\
\hline Jan & $1202 \pm 77^{A}$ & $1206 \pm 122^{A}$ & \\
\hline \multicolumn{4}{|c|}{ Defecation (\% of ingested ${ }^{14} \mathrm{C}$ ) } \\
\hline Apr & $58.9 \pm 3.2^{\mathrm{D}}$ & $74.7 \pm 2.6^{\mathrm{C}}$ & \multirow{4}{*}{$<0.0001$} \\
\hline Jul & $73.5 \pm 3.6^{c}$ & $79.9 \pm 3.6^{\mathrm{BC}}$ & \\
\hline Sep & $76.8 \pm 3.0^{c}$ & $90.9 \pm 1.5^{\mathrm{A}}$ & \\
\hline Jan & $75.8 \pm 1.3^{\mathrm{C}}$ & $86.3 \pm 1.3^{\mathrm{AB}}$ & \\
\hline \multicolumn{4}{|c|}{ Excretion ( $\%$ of ingested ${ }^{14} \mathrm{C}$ ) } \\
\hline Apr & $22.2 \pm 1.4$ & $15.1 \pm 1.2^{c}$ & \multirow{4}{*}{$<0.0001$} \\
\hline Jul & $18.0 \pm 2.1^{\mathrm{B}}$ & $4.1 \pm 0.6^{\mathrm{D}}$ & \\
\hline Sep & $4.5 \pm 0.2^{\mathrm{D}}$ & $2.3 \pm 0.2^{\mathrm{D}}$ & \\
\hline $\mathrm{Jan}$ & $3.9 \pm 0.3^{D}$ & $2.5 \pm 0.1^{D}$ & \\
\hline \multicolumn{4}{|c|}{ Respiration $\left(\%\right.$ of ingested $\left.{ }^{14} \mathrm{C}\right)$} \\
\hline A.pr & $2.1 \pm 0.2^{\mathrm{AB}}$ & $0.8 \pm 0.1^{D}$ & \multirow{4}{*}{0.0003} \\
\hline Jul & $4.1 \pm 0.4^{\mathrm{A}}$ & $2.4 \pm 0.3^{\mathrm{AB}}$ & \\
\hline Sep & $2.9 \pm 0.2 \times$ & $1.8 \pm 0.1^{\mathrm{BC}}$ & \\
\hline Jan & $1.8 \pm 0.4^{\mathrm{BCD}}$ & $1.0 \pm 0.1^{\mathrm{CD}}$ & \\
\hline \multicolumn{4}{|c|}{ Incorporation $\left(\%\right.$ of ingested $\left.{ }^{14} \mathrm{C}\right)$} \\
\hline Apr & $14.2 \pm 1.8^{\mathrm{ABC}}$ & $8.2 \pm 1.0^{\mathrm{CD}}$ & \multirow{4}{*}{0.0001} \\
\hline Jul & $11.4 \pm 0.9^{R C}$ & $11.6 \pm 1.6^{\mathrm{ABC}}$ & \\
\hline Sep & $15.3 \pm 1.6^{\mathrm{AB}}$ & $4.7 \pm 0.4^{\mathrm{D}}$ & \\
\hline Jan & $17.3 \pm 0.6^{\mathrm{A}}$ & $9.9 \pm 0.5^{\mathrm{BC}}$ & \\
\hline
\end{tabular}


unclear if a portion of this dissolved pool of ${ }^{14} \mathrm{C}$ might have simply been non-utilized products of extracellular digestion (i.e. not absorbed; see discussion in Kreeger et al. in press).

Ingestion rates of ${ }^{15} \mathrm{~N}$ and the resulting ${ }^{15} \mathrm{~N}$ budgets did not differ significantly ( $t$-tests for each pairwise case, $p<0.05$ ) between groups of mussels fed the 2 capsule types, which was anticipated because the 2 types of capsules were similar in biochemical and ${ }^{15} \mathrm{~N}$ composition, and because rates of ${ }^{14} \mathrm{C}$ ingestion did not differ between capsule types (Table 1). Therefore, the ${ }^{15} \mathrm{~N}$ budgets of mussels fed capsule Types 1 and 2 were pooled for statistical analyses and the combined ${ }^{15} \mathrm{~N}$ budget is given in Table 2 . The ${ }^{15} \mathrm{~N}$ assimilation efficiency, calculated as the proportion of ingested ${ }^{15} \mathrm{~N}$ that was incorporated by mussels, also differed significantly $(p=0.0003)$ and was much greater in July $(83 \%)$ compared with other times of the year ( 20 to $28 \%$ ) (Table 2 ). Since very little ${ }^{15} \mathrm{~N}$ was excreted (see below), ${ }^{15} \mathrm{~N}$ absorption efficiency (proportion of ingested ${ }^{15} \mathrm{~N}$ either excreted or incorporated) followed a nearly identical seasonal pattern to that for ${ }^{15} \mathrm{~N}$ assimilation efficiency (Table 2).

The assimilation efficiencies for $\left[{ }^{14} \mathrm{C}\right] \mathrm{car}$ bohydrate, $\left[{ }^{14} \mathrm{C}\right]$ protein and $\left[{ }^{15} \mathrm{~N}\right]$ protein by Mytilus edulis are compared in Fig. 1. In each experiment, protein- $\mathrm{N}\left({ }^{15} \mathrm{~N}\right)$ was assimilated better than protein-C $\left({ }^{14} \mathrm{C}\right.$ from Type 2 capsules). A 2-way ANOVA comparing the relative effects of substrate type and experiment month indicated that overall, protein$\mathrm{N}$ was assimilated with significantly $(\mathrm{p}<$ 0.05) greater efficiency compared with carbohydrate, which was assimilated significantly $(p<0.05)$ more efficiently than protein-C. The ANOVA was complicated, however, by a significant ( $p<0.05$ ) interaction between effects of month and substrate type because during July the assimilation efficiency for protein- $N$ was more than 5 times greater than that for either carbohydrate or protein-C.
Rates of ammonium- $\mathrm{N}$ excretion $\left[\mu \mathrm{mol} \mathrm{d}^{-1}(\mathrm{~g}\right.$ AFDTW) ${ }^{-1}$ ] also varied significantly (ANOVA, $\mathrm{p}<$ 0.05 ) among experiments, and were greatest in April and lowest in July (Fig. 2). The proportion of absorbed ${ }^{15} \mathrm{~N}$ that was excreted followed a similar seasonal pattern. However, less than $2 \%$ of ingested ${ }^{15} \mathrm{~N}$ was excreted (Table 2). Alternatively, mussels excreted up to $15 \%$ of ingested $\left[{ }^{14} \mathrm{C}\right.$ )protein (Table 1 ). In contrast to rates of excretion, rates of whole-body protein synthesis ( $\mathrm{mg} \mathrm{d}^{-1}$ mussel $^{-1}$ ) were significantly (ANOVA, $p<0.05)$ greater in July and September than in April or January (Fig. 3). The inverse relationship between rates of ammonium excretion and protein synthesis between April and July was associated with a significant (ANOVA, $\mathrm{p}<0.05$ ) decrease in the reproductive condition of Mytilus edulis (Fig. 4). The gamete volume fraction (i.e.\% ripe) in mussel mantle tissues was greatest in April $(20 \%)$ and lowest in September $(<1 \%)$.

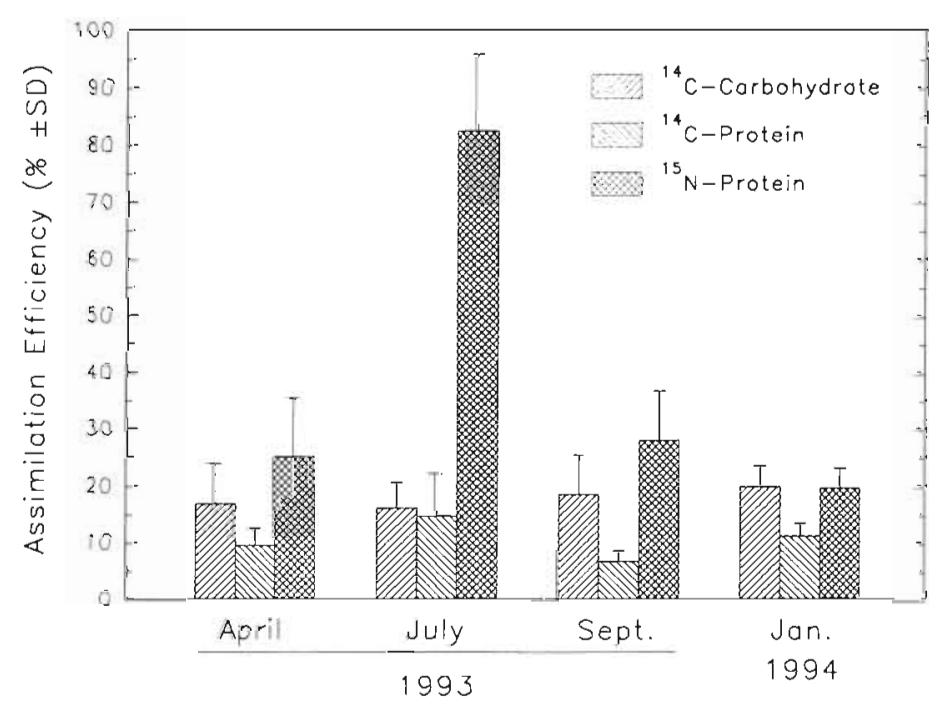

Fig. 1. Mytilus edulis. Mean ( $\pm \mathrm{SE}$ ) assimilation efficiencies for $\left[{ }^{14} \mathrm{C}\right] \mathrm{car}-$ bohydrate, $\left[{ }^{14} \mathrm{C}\right]$ protein and $\left[{ }^{15} \mathrm{~N}\right]$ protein from mixed protein/carbohydrate microcapsules fed to mussels during April, July and September 1993 and January 1994

Table 2. Mytilus edulis. Components of the ${ }^{15} \mathrm{~N}$ budget of mussels fed mixed protein/carbohydrate microcapsules containing $\left[{ }^{15} \mathrm{~N}\right]$ protein. Mean $\left( \pm \mathrm{SE}\right.$ ) weight of ${ }^{15} \mathrm{~N}$ for each component is expressed as a percentage of ingested ${ }^{15} \mathrm{~N}$. For each component, differences among experiments were statistically assessed using ANOVA after arcsine square-root transformation; different superscripted letters indicate significant differences $(p<0.05)$. AE: assimilation efficiency

\begin{tabular}{|c|c|c|c|c|c|}
\hline \multirow{2}{*}{ Physiological component } & \multicolumn{4}{|c|}{ Percentage of ingested ${ }^{15} \mathrm{~N}$} & \multirow[t]{2}{*}{$\mathrm{p}$} \\
\hline & Apr & Jul & Sep & Jan & \\
\hline Excretion & $1.52 \pm 0.32^{\lambda}$ & $0.28 \pm 0.04^{\mathrm{B}}$ & $0.31 \pm 0.03^{\mathrm{B}}$ & $0.42 \pm 0.05^{B}$ & $<0.0001$ \\
\hline Incorporation (AE) & $25.1 \pm 2.1^{\mathrm{BC}}$ & $82.5 \pm 2.5^{A}$ & $28.0 \pm 1.6^{\mathrm{B}}$ & $19.6 \pm 0.6^{C}$ & 0.0003 \\
\hline Absorption & $27.5 \pm 2.2^{8}$ & $83.3 \pm 2.5^{\mathrm{A}}$ & $28.6 \pm 1.6^{\mathrm{B}}$ & $19.9 \pm 0.6^{C}$ & 0.0001 \\
\hline
\end{tabular}




\section{DISCUSSION}

Suspension-feeding bivalves possess a diverse array of physiological adaptations which they use to balance their nutritional requirements from a complex and variable diet. In addition to the potential for regulating food uptake quantitatively (e g. feeding rate, pseudofeces production) and/or qualitatively (pre-and postingestion particle selection), some species are also capable of efficiently recycling endogenous nutrient reserves (for reviews, see Bayne \& Newell 1983, Hawkins \& Bayne 1992). For example, Hawkins (1985) showed that under conditions of low net nitrogen balance, Mytilus edulis can break down endogenous protein and recycle amino- $N$ products with high efficiency. By this means, whole-body protein turnover (WBPT) can mobilize amino acids, some of which can be selectively translocated to satisfy specific biosyn-

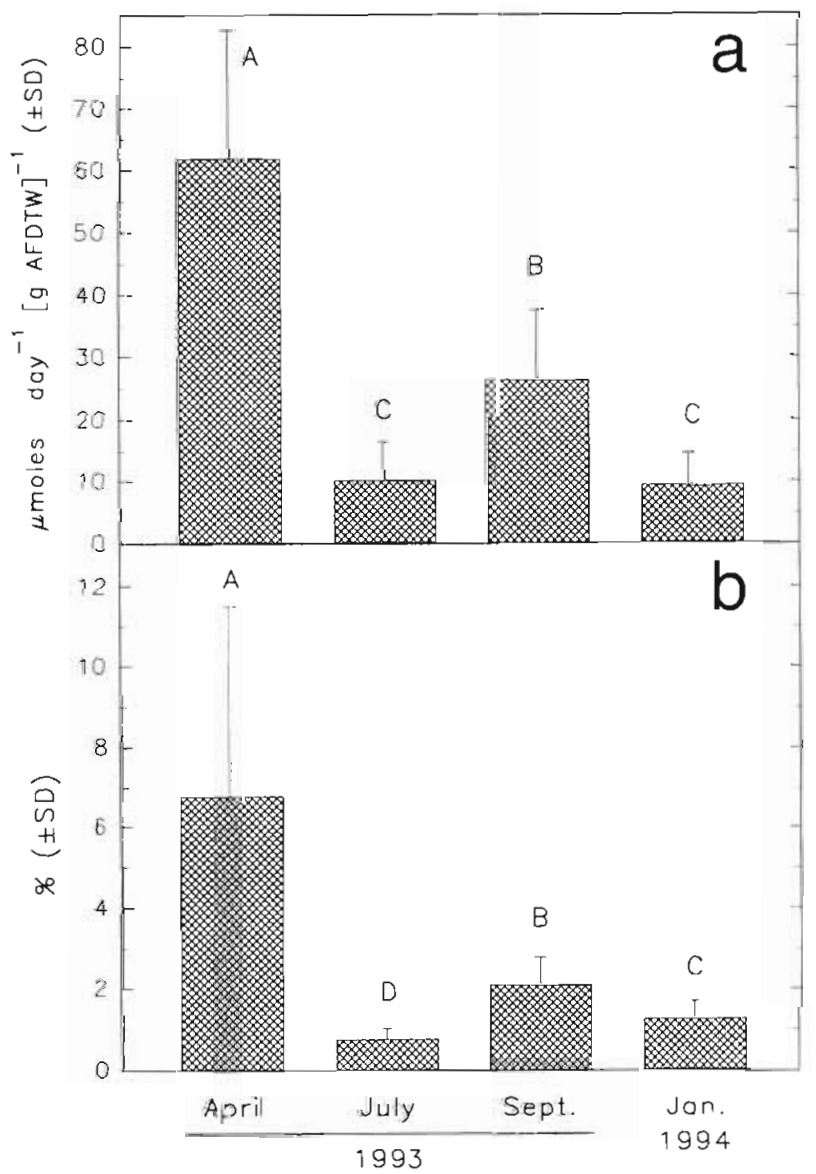

Fig. 2. Mytilus edulis. Excretion by mussels during April, July and September 1993 and January 1994 given as (a) AFDTWspecific rates of ammonium-nitrogen production, and (b) proportion of absorbed ${ }^{15} \mathrm{~N}$ released as DOM. Variation among experiments was statistically analyzed with ANOVA procedures [values in (b) were first arcsine square-root transformed]; significant $(p<0.05)$ differences are denoted by different letters

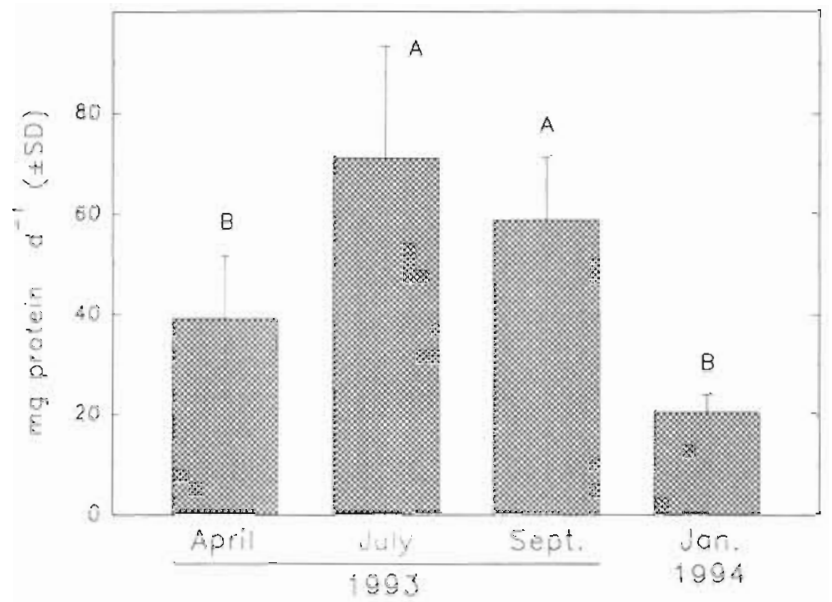

Fig. 3. Mytilus edulis. Rates of whole-body protein synthesis ( $\mathrm{mg} \mathrm{d}^{-1}$ mussel $^{-1}$ ) during April, July and September 1993 and January 1994. Significant differences (ANOVA, $p<0.05$ ) among experiments are denoted by different superscripted letters

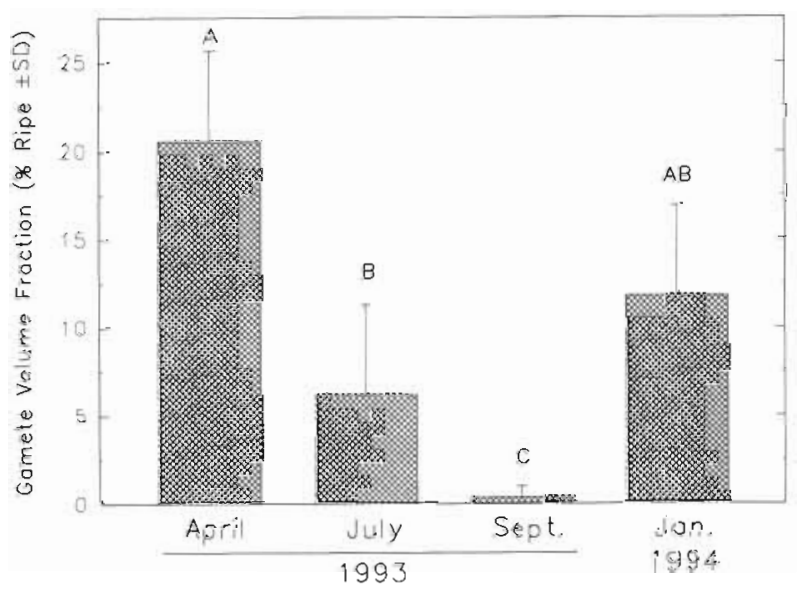

Fig. 4. Mytilus edulis. Reproductive condition of mussels during April, July and September 1993 and January 1994, measured as the volumetric proportion of mantle tissue occupied by ripe gametes ('gamete volume fraction'). Significant differences (ANOVA on arcsine square-root transformed percentages, $p<0.05$ ) among experiments are denoted by different superscripted letters

thetic requirements, whereas less 'essential' amino acids can be catabolized to help meet the energy demand (Hawkins 1991).

In addition to these adaptations, results from the present study clearly demonstrate that Mytilus edulis was able to help satisfy the amino- $\mathrm{N}$ demands of biosynthesis by adjusting the efficiency with which ingested exogenous protein was utilized and conserved. For example, although mussels assimilated dietary carbohydrate (i.e. energy) with similar efficiency (16 to 20\%) throughout the year, the assimilation efficiency of 
dietary protein (as indicated by $\left[{ }^{15} \mathrm{~N}\right]$ protein) varied more than 4 -fold. Although seasonal variation in the assimilation efficiency of dietary carbohydrates has never before been measured in suspension-feeders, it is known that dietary proteins are assimilated with variable efficiency. Hawkins \& Bayne (1984) reported that absorption efficiencies for ${ }^{15} \mathrm{~N}$-labeled microalgae by freshly collected $M$. edulis decreased from $81.1 \%$ in March to $54.9 \%$ in June. Similarly, Kreeger (1993) fed $M$. trossulus on ${ }^{14} \mathrm{C}$-labeled, encapsulated protein, and reported that ${ }^{14} \mathrm{C}$ assimilation efficiencies varied from 5 to $31 \%$ during the year. As a result of this variability in protein assimilation efficiency (and to a lesser degree, seasonal variation in ingestion rates), in situ assimilation rates for bioavailable protein were estimated to vary by more than 7 times (Kreeger 1993). Since the assimilation efficiency for protein-N correlated $\left(R^{2}\right.$ for regression equation $=6.3 \%$ ) with rates of protein synthesis in the present study, mussels were apparently responding to changing protein demands with concomitant adjustments in the utilization of absorbed exocgenous protein.

An intriguing result was that protein- $\mathrm{N}$ was assimilated significantly more efficiently than protein-C, which illustrates the usefulness of a multiple isotope approach for discerning the metabolic fate of biochemicals absorbed by suspension-feeders. In a similar approach, Chalermwat et al. (1991) reported that clams Mulinia lateralis assimilated ${ }^{35} \mathrm{~S}$ from dualisotope-labeled bacteria with significantly greater efficiency than ${ }^{3} \mathrm{H}_{\text {i }}$ probably because the nutritional requirements for sulfur-containing amino acids exceeded the average amino acid requirements. In the present study, high rates of assimilation and incorporation of protein- $\mathrm{N}$ did not reflect protein utilization per se, but instead reflected increased conservation of dietary amino- $\mathrm{N}$ relative to dietary $\mathrm{C}$ (from both carbohydrate and protein). Hawkins (1985) also reported that the elemental turnover of $\mathrm{N}$ by Mytilus edulis is consistently more conservative than $\mathrm{C}$ turnover.

The difference in $\mathrm{N}$ and $\mathrm{C}$ assimilation was especially clear in July when protein- $\mathrm{N}$ was assimilated 5 times more efficiently than protein- $C$. These results indicate that a large proportion of absorbed proteins was fully digested to amino- $\mathrm{N}$ and amino- $\mathrm{C}$, and whereas most of the amino- $\mathrm{N}$ was conserved (i.e. ${ }^{15} \mathrm{~N}$ assimilation), most of the amino- $\mathrm{C}$ was instead lost as excreta (i.e. the difference between ${ }^{15} \mathrm{~N}$ and ${ }^{14} \mathrm{C}$ assimilation). The mussel's qualitative demands for biosynthesis (i.e. essential amino acids) must have therefore been vastly exceeded by the quantitative biosynthetic nitrogen demand (i.e. amino-N) (see also Kreeger et al. in press). Losses of absorbed but non-assimilated amino-C in July must have occurred mostly via defecation since direct measurement of $\left[{ }^{14} \mathrm{C}\right] \mathrm{DOM}$ excretion comprised only $4 \%$ of the amino- ${ }^{14} \mathrm{C}$ budget. Hence, apparent absorption efficiencies for carbon that are calculated from our data (and those in related carbon balance studies) might underestimate true absorption efficiencies since traditional calculation methods assume that fecal carbon is unabsorbed

Protein synthesis can account for $>16 \%$ of basal energy requirements (Hawkins 1985). Hydrolysis of amino acids and the transamination of amino- $\mathrm{N}$ for biosynthesis are also energy-intensive processes (Lehninger 1970), and it is noteworthy that amino-C generated as a by-product of this process was excreted and not transferred to the tricarboxylic acid cycle for use as a catabolic fuel. Clearly, mussels should have catabolized this 'in hand' energy source if they were nutritionally limited by energy. Indeed, the continuous conservation of amino- $\mathrm{N}$ relative to amino- $\mathrm{C}$ among the 4 seasonal experiments, and the invariable utilization of readily catabolizable substrates such as dietary carbohydrate, suggest that mussels were more likely to have been nutritionally limited by their quantitative amino- $\mathrm{N}$ requirements rather than either their energy demand or their qualitative amino acid requirements.

The reproductive condition of mussels in Whitsand Bay was greatest in spring and lowest in fall, which is similar to the pattern described previously by Hawkins et al. (1985) for Whitsand Bay mussels. This pattern is typical of bivalves living in temperate habitats. Spawning usually occurs in spring and early summer when food supplies for larvae are abundant. In fall, bivalves accumulate storage carbohydrates as fuel for overwintering and subsequent gametogenesis during winter (Gabbott 1976, 1983). Kreeger (1993) reported that Mytilus trossulus assimilated dietary protein with significantly greater efficiency when the mussels were undergoing gametogenesis compared with the quiescent period. However, in this study, $M$. edulis assimilated both protein- $\mathrm{C}$ and protein- $\mathrm{N}$ most efficiently during the postspawning quiescent period. These results are supported by previous reports (Bayne 1973a, b, Bayne \& Widdows 1978) that O/N ratios of Whitsand Bay mussels are lowest, and so protein serves as a primary catabolic substrate, during gametogenesis. There could be several reasons for the apparently equivocal patterns in protein assimilation between $M$. edulis and $M$. trossulus, such as sitespecific differences in protein availability and diet quality, genetic differences in gametogenic protein requirements, and/or genetic differences in the capacity to recycle endogenous protein reserves (for review, see Hawkins \& Bayne 1991).

Nitrogen utilization was most efficient in July when ingestion rates were at their lowest and rates of protein synthesis were greatest. Mussels responded physiologically to these pressures on $\mathrm{N}$ balance by limit- 
ing excretory amino- $\mathrm{N}$ losses and maximizing the transamination of digested proteins to amino- $\mathrm{N}$ for use in biosynthesis. Such flexibility in protein utilization demonstrates that mussels possess substantial metabolic adaptations for controlling the relative anabolic and catabolic fates of exogenous protein. Since they can also regulate the recycling of endogenous amino$\mathrm{N}$ by controlling protein breakdown rates (Hawkins 1991. Hawkins \& Bayne 1992), mussels possess a powerful and complex suite of metabolic adaptations for optimizing nitrogen balance, and protein utilization in Mytilus edulis should be considered as a highly plastic process

Acknowledgements. R. Smith, S. Jones, K. Kreeger and M. Day rendered excellent technical support. This project benefited from technical suggestions and interpretive comments by C. J. Langdon and R. I. E. Newell. This material is based upon work supported by the North Atlantic Treaty Organization under National Science Foundation Grant No. GER 9255310 awarded to D. A. K. in 1992. Supplemental funds for research support and materials were graciously provided by the Plymouth Marine Laboratory of the U.K. Natural Environment Research Council.

\section{LITERATURE CITED}

Bayne BL (1973a) Aspects of the metabolism of Mytilus edulis during starvation. Neth J Sea Res 7:399-410

Bayne BL (1973b) Physiological changes in Mytilus edulis L. induced by temperature and nutritive stress. $J$ mar biol Ass UK 53:39-58

Bayne BL, Hawkins AJS, Navarro E, Iglesias JIP (1989) The effects of seston concentration on feeding, digestion and growth in the mussel Mytilus edulis. Mar Ecol Prog Ser 55: $47-54$

Bayne BL, Iglesias JIP, Hawkins AJS, Navarro E, Héral M, Deslous-Paoli JM (1993) Feeding behaviour of the mussel, Mytilus edulis L.; responses to variations in both quantity and organic content of seston. J mar biol Ass UK 73: $813-829$

Bayne BL, Newell RC (1983) Physiological energetics of marine Mollusca. In: Saleuddin ASM, Wilbur KM (eds) The Mollusca, Vol 4. Academic Press, New York, p 407-515

Bayne BL, Widdows J (1978) The physiological ecology of two populations of Mytilus edulis L. Oecologia 37:137-162

Berg JA, Newell RIE (1986) Temporal and spatial variations in the composition of seston available to the suspension feeder Crassostrea virginica. Estuar coast Shelf Sci 23 375-386

Bricelj VM, Malouf RE (1984) Influence of algal and suspended sediment concentrations on the feeding physiology of the hard clam Mercenaria mercenaria. Mar Biol 84 $155-165$

Burt WV (1955) Distribution of suspended materials in Chesapeake Bay. J mar Res 14:47-62

Chalermwat K, Jacobsen TR, Lutz RA (1991) Assimilation of bacteria by the dwarf surf clam Mulinia lateralis (Bivalvia Mactridae). Mar Ecol Prog Ser 71:27-35

Chanut JP, Poulet SA (1982) Short-term variability of the size spectra of suspended particles in a rapidly changing environment. Estuar coast Shelf Sci 15:497-513
Cranford PJ, Hargrave BT (1994) In situ time-series measurement of ingestion and absorption rates of suspension-feeding bivalves: Placopecten magellanicus. Limnol Oceanogr 39:730-738

Fegley SR, MacDonald BA, Jacobsen TR (1992) Short-term variation in the quantity and quality of seston available to benthic suspension-feeders. Estuar coast Shelf Sci 34: 393-412

Gabbott PA (1976) Energy metabolism. In: Bayne BL (ed) Marine mussels. Cambridge University Press, New York, p 293-355

Gabbott PA (1983) Developmental and seasonal metabolic activities in marine molluscs. In: Hochachka PW (ed) The mollusca, Vol 2. Academic Press, New York, p 165-217

Galvao HM, Fritz AT (1991) Microbial trophodynamics in a salt-marsh. Mar microb Food Webs 5:13-26

Hawkins AJS (1985) Relationships between the synthesis and breakdown of protein, dietary absorption and turnovers of nitrogen and carbon in the blue mussel, Mytilus edulis L. Oecologia 66:42-19

Hawkins AJS (1991) Protein turnover: a functional appraisal. Funct Ecol 5(2):222-233

Hawkins AJS, Bayne BL (1984) Seasonal variation in the balance between physiological mechanisms of feeding and digestion in Mytilus edulis (Bivalvia: Mollusca). Mar Biol 83:233-240

Hawkins AJS, Bayne BL (1985) Seasonal variation in the relative utilization of carbon and nitrogen by the mussel Mytilus edulis: budgets, conversion efficiencies and maintenance requirements. Mar Ecol Prog Ser 25:181-188

Hawkins AJS, Bayne BL (1991) Nutrition of marine mussels factors influencing the relative utilizations of protein and energy. Aquaculture 94:177-196

Hawkins AJS, Bayne BL (1992) Physiological interrelations, and the regulation of production. In: Gosling EM (ed) The mussel Mytilus: ecology, physiology, genetics and culture. Elsevier, New York. p 171-222

Hawkins AJS, Bayne BL, Day AJ, Rusin J, Worrall CM (1989) Genotype-dependent interrelations between energy metabolism, protein metabolism and fitness. In: Ryland JS, Tyler PA (eds) Reproduction, genetics and distributions of marine organisms, 23rd Eur Mar Biol Symp. Olson and Olson, Fredensborg, p 283-292

Hawkins AJS, Salkeld PH, Bayne BL, Gnaiger E, Lowe DM (1985) Feeding and resource allocation in the mussel Mytilus edulis: evidence for time-averaged optimization. Mar Ecol Prog Ser 20:273-287

Iglesias JIP, Navarro E, Alvarez Jorna P, Armentia I (1992) Feeding, particle selection and absorption in cockles Cerastoderma edule ( $L$.) exposed to variable conditions of food concentration and quality. J exp mar Biol Ecol 162: $177-198$

Kiørboe T, Møhlenberg F (1981) Particle selection in suspension-feeding bivalves. Mar Ecol Prog Ser 5:291-296

Kiørboe T, Møhlenberg F, Nøhr O (1980) Feeding, particle selection and carbon absorption in Mytilus edulis in different mixtures of algae and resuspended bottom material. Ophelia 19:193-205

Kreeger DA (1993) Seasonal patterns in the utilization of dietary protein by the mussel Mytilus trossulus. Mar Ecol Prog Ser 95:215-232

Kreeger DA, Hawkins AJS, Bayne BL (in press) Use of duallabeled microcapsules to discern the physiological fates of dietary carbohydrate, protein-carbon and protein-nitrogen in suspension-feeding organisms. Limnol Oceanogr

Kreeger DA, Langdon CJ (1994) Digestion and assimilation of protein by Mytilus trossulus (Bivalvia: Mollusca) fed 
mixed carbohydrate/protein microcapsules. Mar Biol 118 : $479-488$

Langdon CJ, Newell RIE (1990) Utilization of detritus and bacteria as food sources by two bivalve suspension-feeders, the oyster Crassostrea virginica and the mussel Geukensia demissa. Mar Ecol Prog Ser 58:299-310

Lehninger AL (1970) Biochemistry: the molecular basis of cell structure and function. Worth Publishers, Inc., New York

Lowe DM, Moore MN, Bayne BL (1982) Aspects of gametogenesis in the marine mussel Mytilus edulis L. J mar biol Ass UK 62:133-145

MacDonald BA. Ward JE (1994) Variation in food quality and particle selectivity in the sea scallop Placopecten magellanicus (Mollusca: Bivalvia). Mar Ecol Prog Ser 108:251-264

Mayzaud P, Chanut JP, Ackman RG (1989) Seasonal changes of the biochemical composition of marine particulate matter with special reference to fatty acids and sterols. Mar Ecol Prog Ser 56:189-204

Navarro E, Iglesias JIP, Ortega MM (1992) Natural sediment as a food source for the cockle Cerastoderma edule (L.): effect of variable particle concentration on feeding, digestion and the scope for growth. J exp mar Biol Ecol 156 $69-87$

Newell RIE, Jordan SJ (1983) Preferential ingestion of organic material by the American oyster Crassostrea virginica.

This article was submitted to the editor
Mar Ecol Prog Ser 13:7-53

Prins TC, Smaal AC (1989) Carbon and nitrogen budgets of the mussel Mytilus edulis L. and the cockle Cerastoderma edule (L.) in relation to food quality. Scientia mar 53:477-482

Prins TC, Smaal AC, Pouwer AJ (1991) Selective ingestion of phytoplankton by the bivalves Mytilus edulis L. and Cerastoderma edule (L.). Hydrobiol Bull 25:93-100

Sommer U (1989) Nutrient status and nutrient competition of phytoplankton in a shallow, hypertrophic lake. Limno] Oceanogr 34:1162-1173

Soniat TM, Ray SM, Jeffrey LM (1984) Components of the seston and possible available food for oysters in Galveston Bay, Texas. Contr mar Sci 27:127-141

Urabe J (1993) N and P cycling coupled by grazers' activities: food quality and nutrient release by zooplankton. Ecology $74(8): 2337-2350$

Van Valkenburg SD, Jones JK, Heinle DR (1978) A comparison by size class and volume of detritus versus phytoplankton in Chesapeake Bay. Estuar coast Shelf Sci 6:569

Winter JE (1976) Feeding experiments with Mytilus edulis L. at small laboratory scale. II. The influence of suspended silt in addition to algal suspensions on growth. In: Persoone $\mathrm{G}$, Jaspers $\mathrm{E}$ (eds) Research in mariculture at laboratory-and pilot-scale, Vol. 1. 10th Eur Mar Biol Symp. Universa Press, Wetteren, p 583-600

Manuscript first received: February 17, 1995

Revised version accepted: April 12, 1995 